\title{
Uniwersytet Rzeszowski
}

\section{Zadłużenie rolników w Polsce w aspekcie przemian strukturalnych i koniunktury w rolnictwie}

\section{INDEBTEDNESS OF FARMERS IN POLAND IN LIGHT OF STRUCTURAL CHANGES AND ECONOMIC FLUCTUATIONS IN AGRICULTURE}

\begin{abstract}
$W$ artykule dokonano analizy dynamiki oraz struktury zobowiazań kredytowych rolników wobec banków $w$ Polsce $w$ latach 1996-2018. Zadtużenie kredytowe rolników przedstawiono na tle przemian strukturalnych $i$ koniunktury $w$ rolnictwie. Założono, że korzystna koniunktura $w$ rolnictwie stymuluje wzrost zadtużenia rolników w bankach. Podobnie założono, że proces koncentracji struktury agrarnej oraz wzrost technicznego uzbrojenia pracy i technicznego uzbrojenia ziemi będa czynnikami sprzyjajacymi wzrostowi zadtużenia kredytowego rolników. Badania nie daty jednoznacznej odpowiedzi na postawione tezy badawcze. Ujawniono dodatniq wspótzmienność pomiędzy zadhuzeniem kredytowym rolników a koniunkturq w rolnictwie, a także procesem substytucji nakładów pracy i ziemi przez nakłady kapitatu. Analiza regresji wykazała, że stymulanta zadlużenia kredytowego sq naklady inwestycyjne $w$ rolnictwie, natomiast koncentracja struktury agrarnej oraz poprawa relacji ziemia/praca prowadzi do zmniejszenia przyrostów zadtużenia.
\end{abstract}

Słowa kluczowe: gospodarstwa rolne, kredyt bankowy, koniunktura w rolnictwie, przemiany strukturalne.

JEL Code: G21, Q14.

\section{Wstęp}

Dostęp do kredytu w sytuacji ograniczonego wykorzystania innych źródeł finansowania zewnętrznego w rolnictwie, a także niewielkich możliwości akumulacji funduszy własnych ma istotny wpływ na zachowania produkcyjne, inwestycyjne i konsumpcyjne rolników. Współzależności rolnictwa z rynkiem kredytowym wynikają przynajmniej z kilku powodów, m.in. względnie wysokiej relacji kapitał-praca oraz kapitał-produkcja, czyli wysokiej kapitałochłonności rolnictwa, specyfiki aktywów gospodarstw rolnych (w szczególności ziemi), zazwyczaj długiego cyklu produkcji, występowania związków między stopami procentowymi, a wartością ziemi rolnej, wysokiej zmienności uzyskiwanych efektów produkcyjnych ${ }^{1}$. Gospodarstwa rolne, które produkują na rynek powin-

\footnotetext{
${ }^{1}$ R. Bierlen, P.J. Barry, B.L. Dixon, B. Ahrendsen: Credit Constraints, Farm Characteristics and the Farm Economy. American Journal of Agricultural Economics, 80(4)/1998, s. 708-723; P.J. Barry, L.J. Robison: Agricultural Finance: Credit, Credit Constraints, and Consequences. Handbook of Agricultural Economics,
} 
ny mieć zatem stały dostęp do kredytu, oferowanego na warunkach cenowych i innych dostosowanych do charakterystyk przyrodniczych, produkcyjno-technicznych i ekonomiczno-finansowych rolnictwa ${ }^{2}$. Korzystanie z kredytów bankowych, zwłaszcza długoterminowych, poprzez procesy inwestycyjne przyczynia się do zwiększenia potencjału wytwórczego, poprawy wydajności pracy, a także wzrostu produktywności i dochodowości gospodarstw ${ }^{3}$. Rolnicy należą jednak do tych klientów banków, którzy są najbardziej narażeni na niedoskonałości rynku kredytowego, takie jak ograniczenia kredytowe oraz racjonowanie kredytów. Ograniczenia kredytowe mają źródła wewnętrzne, wynikające ze specyfiki produkcji rolnej i gospodarstwa rolnego oraz specyfiki rolników jako przedsiębiorców, a także źródła zewnętrzne o charakterze sektorowym i makroekonomicznym ${ }^{4}$.

W niniejszym opracowaniu dokonano analizy poziomu, struktury i dynamiki zadłużenia kredytowego gospodarstw rolniczych w Polsce. Celem badań było poszukiwanie odpowiedzi na pytanie, czy zadłużenie kredytowe rolników jest powiązane z koniunkturą $\mathrm{w}$ rolnictwie oraz zmianami strukturalnymi $\mathrm{w}$ tym sektorze. Założono, że zmiany poziomu zadłużenia rolników $\mathrm{w}$ bankach będą powiązane $\mathrm{z}$ koniunkturą $\mathrm{w}$ rolnictwie wyrażoną przez indeks nożyc cen oraz wskaźnik koniunktury IRGAGR, który wyraża subiektywne oceny rolników w kwestii sytuacji ekonomicznej i perspektyw rozwoju swoich gospodarstw. Ponadto założono, że procesy koncentracji struktury agrarnej oraz wzrost relacji ziemia/praca, a także kapitał/ziemia i kapitał/praca, będą dodatnio skorelowane z zadłużeniem rolników. Dla oceny współzależności tych zmiennych zastosowano analizę regresji liniowej wielorakiej. Aby dokonać statystycznej weryfikacji przyjętych założeń analizą objęto relatywnie długi okres, tj. lata 1996-2018 (łącznie 23 lata). $\mathrm{Z}$ uwagi na dostępność danych, niektóre aspekty podejmowanej problematyki, badano w nieco krótszym okresie, mieszczącym się jednak w ww. ramach czasowych. Źródłem materiałów do badań były dane statystyczne uzyskane z NBP, GUS, Eurostat, systemu rachunkowości rolnej FADN oraz Agencji Restrukturyzacji i Modernizacji Rolnictwa (ARiMR).

\section{Wyniki badań i dyskusja}

Zadłużenie polskich rolników w bankach wzrosło w latach 1996-2018 z 3,8 mld zł do 34,1 mld zł (rys. 1). Oznacza to blisko 9-krotny wzrost nominalny, zaś wzrost realny wyniósł 330\% (jako deflator zastosowano indeks inflacji CPI). W strukturze zadłużenia kredyty długoterminowe, a ściślej te, których okres spłaty przekraczał 1 rok, na koniec

1(A)/2001, s. 513-571; P. Kułyk: Uwarunkowania rynku kredytowego w rolnictwie. Ujęcie makroekonomiczne, Progress in Economic Sciences, 1/2014, s. 153-164.

2 J. Kulawik, B. Wieliczko: Polityka pieniężna a kredytowanie rolnictwa. Zagadnienia Ekonomiki Rolnej, 337(4)/2013, s. 20-40.

${ }^{3}$ M. Wasilewski, M. Mądra: Efektywność gospodarstw indywidualnych w zależności od zadłużenia i siły ekonomicznej. Ekonomika i Organizacja Gospodarki Żywnościowej, 64/2008, s. 87-99.

${ }^{4}$ S. Blancard, J.P. Boussemart, W. Briec, K. Kerstens: Short- and Long-Run Credit Constraints in French Agriculture: A Directional Distance Function Framework Using Expenditure-Constrained Profit Functions. American Journal of Agricultural Economics, 88(2)/2006, s. 351-364; R. Kata: Endogeniczne i instytucjonalne czynniki kształtujące powiązania finansowe gospodarstw rolnych z bankami, Wyd. Uniwersytetu Rzeszowskiego, Rzeszów 2011. 
2018 r. stanowiły $84,7 \%$. W badanym okresie widoczna była tendencja do wzrostu udziału kredytów długoterminowych, gdyż jeszcze w 1996 r. stanowiły one 55,3\% w strukturze zadłużenia, a ich średni udział w latach 1996-2003 wynosił 67,1\%, natomiast średni udział w okresie poakcesyjnym (2004-2018) wyniósł 83,4\%. Nominalnie zadłużenie rolników z tytułu kredytów długoterminowych wzrosło z niespełna 2,1 mld zł na koniec 1996 r. do 28,9 mld zł na koniec 2018 r.

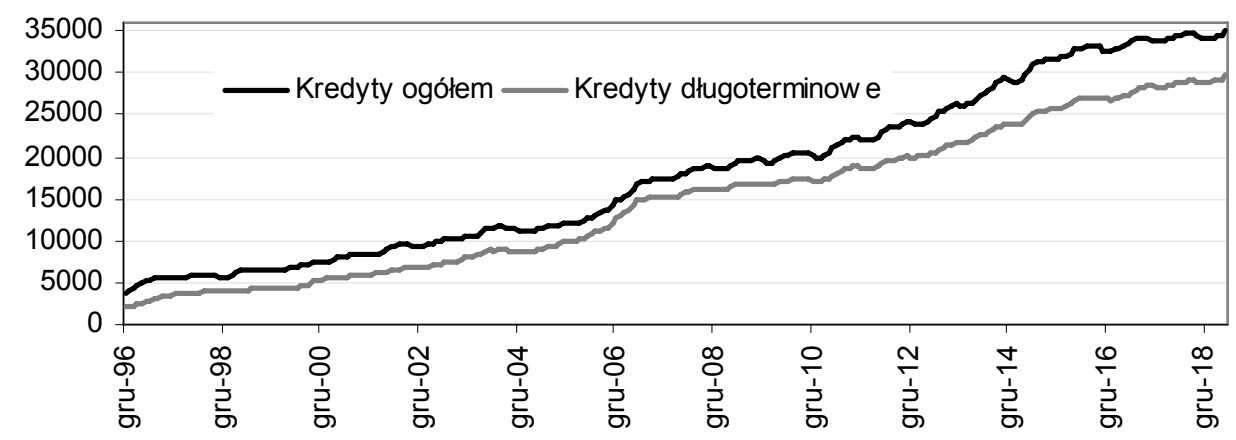

Rysunek 1. Zobowiązania kredytowe rolników w Polsce w latach 1996-2018 (w mln zł)

Źródło: Dane NBP, https://www.nbp.pl/home.aspx?f=/statystyka/pieniezna_i_bankowa/nal_zobow.html

W okresie przedakcesyjnym akumulacja kapitału własnego w gospodarstwach rolnych była niska, a wielu rolników pamiętając problemy ze spiralą zadłużenia gospodarstw z początku lat 90., wykazywało awersję kredytową, rezygnując z kredytów bankowych i tym samym możliwości uzyskania korzyści, wynikających z efektu dźwigni finansowej. Istotną zmianą w tej sferze było przystąpienie Polski do UE i objęcie rolnictwa wsparciem w postaci dopłat bezpośrednich oraz środków przeznaczonych na rozwój gospodarstwach rolnych. W okresie poakcesyjnym, rolnicy w mniejszym stopniu korzystali z kredytów na potrzeby podtrzymania płynności finansowej i finansowania bieżących wydatków gospodarstw rolnych, a w coraz większym stopniu finansowali kredytami bankowymi procesy rozwojowe (w szczególności inwestycje). Świadczy o tym fakt, że w latach 2004-2017 nakłady inwestycyjne w rolnictwie wzrosły nominalnie o $144,5 \%$ (realnie o 93,9\%), zaś zadłużenie rolników w bankach wzrosło nominalnie o 198,3\% (realnie o 136,6\%). Skumulowana wartość inwestycji w rolnictwie w latach 2004-2017 to $57 \mathrm{mld}$ zł. Biorąc pod uwagę wzrost zadłużenia rolników w tym okresie, można szacować, że kredyty bankowe pokryły około 39-40\% wydatków inwestycyjnych w rolnictwie (nie licząc wydatków na zakup ziemi).

Dynamika zadłużenia rolników w bankach w latach 1996-2018 wykazywała dosyć dużą zmienność (rys. 2). W ujęciu nominalnym zadłużenie rolników rosło nieprzerwanie w całym badanym okresie. Natomiast w ujęciu realnym spadek zadłużenia - w stosunku do roku poprzedniego o 7,8\% - miał miejsce w roku 1998. Wysokie przyrosty zadłużenia w ujęciu nominalnym, ale także realnym, miały miejsce w roku 1997, następnie w latach 1999-2003, a w okresie poakcesyjnym w latach 2006-2008 i 2011-2013. Niska, ale wzrostowa dynamika nominalnego i realnego zadłużenia miała miejsce w latach 20042005, a dalej w latach 2009-2010 oraz w roku 2016 i 2018. Największy wzrost zadłużenia, w stosunku do roku poprzedniego miał miejsce w 2006 r. (nominalnie o 23,6\%) oraz 
w 2007 r. (17,5\%). Należy przypuszczać, że duże wahania w poziomie zadłużenia rolników, a zatem także ich popytu kredytowego, mogły być konsekwencją zmian w koniunkturze $\mathrm{w}$ rolnictwie.

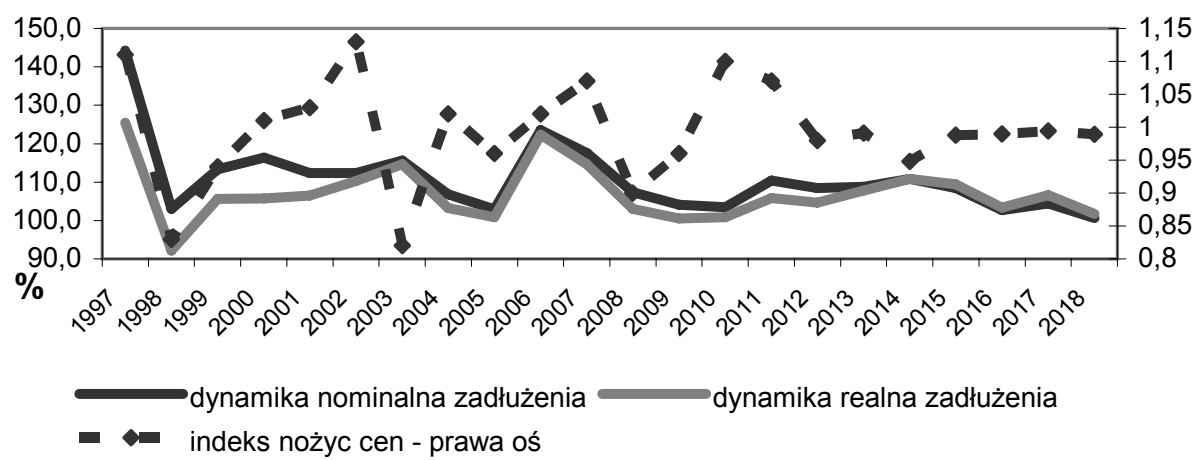

Rysunek 2. Dynamika zadłużenia rolników (rok poprzedni $=100 \%$ ) w ujęciu nominalnym i realnym oraz indeks nożyc cen w rolnictwie w latach 1997-2018

Źródło: Dane NBP (jak rys. 1) oraz Roczniki statystyczne rolnictwa z lat 1997-2018, GUS, Warszawa.

Koniunkturę w rolnictwie można wyrażać za pomocą różnych miar. Jedną z najbardziej obiektywnych jest indeks nożyc cen, czyli relacja cen produktów rolnych sprzedawanych do towarów i usług zakupywanych przez gospodarstwa indywidualne w rolnictwie. Jak widać na rysunku 2 indeks nożyc cen w latach 1996-2012 wykazywał bardzo dużą zmienność. Dopiero w latach 2013-2018 indeks ten ustabilizował się na poziomie 0,98-099. Sama stabilizacja tego indeksu jest korzystna dla rolników, bowiem ogranicza ryzyko cenowe $\mathrm{w}$ rolnictwie, jednakże poziom tego indeksu poniżej 1,0 oznacza, że w każdym kolejnym roku wzrost cen środków do produkcji rolnej był wyższy, niż wzrost cen produktów rolnych. Taka sytuacja nie sprzyjała dochodowości produkcji rolnej. Interesujące jest natomiast to, czy wahania koniunktury w rolnictwie wyrażone indeksem nożyc cen są skorelowane z poziomem i dynamiką zadłużenia kredytowego rolników. Wykres dynamiki zadłużenia rolników (rys. 2) wskazuje, że pogorszenie koniunktury w rolnictwie w latach 1998-1999 (nożyce cen na poziomie odpowiednio: 0,83 i 0,94) oraz w latach 2008-2009 $(0,90$ i 0,96) współwystępowało z wyraźnym zmniejszeniem dynamiki zadłużenia. Ponadto w latach 2008-2009 odczuwane były skutki światowego kryzysu finansowego i spowolnienia gospodarczego, które negatywnie wpłynęły na akcję kredytową banków, także w rolnictwie. Daje się zauważyć z kolei (rys. 2), że poprawa relacji cenowych współwystępowała ze wzrostem dynamiki zadłużenia (za wyjątkiem roku 2003).

Analiza statystyczna wskazuje, że pomiędzy poziomem zadłużenia rolników a indeksem nożyc cen istnieje dodatnia, ale bardzo słaba i nieistotna statystycznie korelacja $\left(\mathrm{r}_{\mathrm{xy}}=0,018\right)$. Natomiast pomiędzy dynamiką zadłużenia rolników w ujęciu realnym, a nożycami cen współczynnik korelacji Pearsona wynosi 0,389 i jest istotny statystycznie (przy $\mathrm{p}<0,05$ ). Dodatni znak współczynnika sugeruje, że poprawa relacji cenowych w rolnictwie sprzyja wzrostowi zadłużenia rolników. Taki kierunek zależności może wynikać $\mathrm{z}$ faktu, że w strukturze zadłużenia kredytowego rolników dominują kredyty długoterminowe. Kredyty inwestycyjne (łącznie z kredytami na zakup nieruchomości) 
stanowiły w latach 2004-2018 średnio 68,4\% w strukturze zadłużenia rolników (w latach 1996-2003 - 55,4\%). W finansowaniu przedsięwzięć inwestycyjnych konieczny jest wkład własny. Kiedy zatem koniunktura w rolnictwie poprawia się, to rolnicy są bardziej skłonni podejmować inwestycje, ponadto w wyniku poprawy dochodowości produkcji rolnej, są oni w stanie łatwiej zgromadzić środki na wkład własny.

Dla ustalenia powiązań między zadłużeniem kredytowym rolników a koniunkturą w rolnictwie, w ujęciu subiektywnym, wykorzystano wskaźnik koniunktury IGRAGR opracowany przez Instytut Rozwoju Gospodarczego Szkoły Głównej Handlowej w Warszawie (SGH). Badania koniunktury w rolnictwie prowadzone od 1999 roku przez IRG SGH bazują na populacji ok. 1600 gospodarstw rolnych. Wskaźnik koniunktury SGH ma charakter endogeniczny oraz subiektywny, bowiem opisuje koniunkturę w rolnictwie z perspektywy ocen kierowników gospodarstw rolnych ${ }^{5}$. Analiza nie wykazała istotnej statystycznie korelacji pomiędzy dynamiką zadłużenia rolników w bankach a koniunkturą w rolnictwie wyrażoną przez wskaźnik IRGAGR (dane dla lat 1999-2018), natomiast istotna statystycznie, umiarkowanie silna i dodatnia współzmienność $\left(\mathrm{r}_{\mathrm{xy}}=0,598\right)$ występuje pomiędzy tym wskaźnikiem, a realnym poziomem zadłużenia kredytowego rolników (tab. 2). IRG SGH w swoich badaniach określa także odsetek rolników deklarujących zamiar wzięcia kredytu bankowego. Analiza trendów, jakie w tym zakresie kształtowały się w latach 1999-2018 wskazuje, że pomimo generalnej poprawy nastrojów i ocen rolników w zakresie perspektyw ekonomicznych gospodarstwa, obserwowanych w latach 2009-2018, sukcesywnie zmniejsza się odsetek ankietowanych, którzy deklarują chęć pobrania kredytu. Odsetek ten zmniejszył się z ponad 50\% w roku 2007 (maksimum dla okresu 1999-2018) do 27,8\% (na koniec 2018 r. ${ }^{6}$. Sukcesywnie maleje też odsetek gospodarstw, które zamierzają zaciagnąc kredyt preferencyjny (z 65\% w roku 2001 do 30,8\% na koniec 2018 r.). Ten spadek zainteresowania rolników kredytami pomimo poprawy koniunktury (w ujęciu subiektywnym) może świadczyć, że to inne czynniki, niezwiązane $\mathrm{z}$ koniunkturą $\mathrm{w}$ rolnictwie miały decydujący wpływ na popyt kredytowy rolników.

Czynnikiem determinującym popyt kredytowy rolników mogą być przemiany strukturalne, które prowadzą do zmiany w relacjach ziemia/praca w gospodarstwach rolnych oraz substytucji nakładów pracy i ziemi przez nakłady kapitału. W latach 1996-2018 w polskim rolnictwie postępowała koncentracja struktury agrarnej, będąca efektem dwóch równoległych procesów. Jednym z nich, był znaczny spadek użytków rolnych, sięgający 3,26 mln ha UR, czyli 18,2\% w stosunku do powierzchni użytków rolnych z roku 1996 (tab. 1). Średnioroczny spadek użytków rolnych wynosił w całym badanym okresie $1,05 \%$, przy czym nieco wyższe tempo „wypadania” ziemi z użytko-

\footnotetext{
${ }^{5}$ Podstawą badań jest ankieta kierowana do rolników, zawierająca pytania, na które respondenci udzielają odpowiedzi: większe - mniejsze, lepiej - gorzej. Wskaźnik obliczany jest na podstawie subiektywnych ocen rolników w zakresie zmian przychodów pieniężnych gospodarstwa (waga 2) oraz ich ocen w kwestii sytuacji ekonomicznej i perspektyw rozwoju gospodarstwa (waga 1) (IRG SGH: Koniunktura w rolnictwie IV kwartał 2018. SGH, Warszawa 2018).

${ }^{6}$ Próba badawcza IRG SGH nie jest reprezentatywna dla całego polskiego rolnictwa ze względu na dominującą liczebność gospodarstw względnie silniejszych ekonomicznie, niemniej jednak wyniki badań są miarodajne dla gospodarstw towarowym (A. Grzelak: Koniunktura w rolnictwie w Polsce w świetle wybranych metod. Roczniki Naukowe SERiA, t. XVI, z. 2/2014, s. 68-72).
} 
wania rolniczego, tj. 1,28\% średniorocznie, miało miejsce $\mathrm{w}$ okresie przedakcesyjnym (1996-2003). Zmniejszeniu areału użytków rolnych towarzyszył spadek liczby gospodarstw rolnych (powyżej 1 ha UR) sięgający w całym badanym okresie 31,7\% (z 2052 tys. do 1401 tys. gospodarstw). Z roku na rok, liczba gospodarstw zmniejszała się o prawie 1,9\%, a zatem niemal 2-krotnie szybciej niż areał użytków rolnych. W efekcie przeciętna powierzchnia gospodarstwa rolnego wzrosła w latach 1996-2018, aż o 35,8\%, tj. z 7,8 ha UR do 10,5 ha UR. O przyspieszeniu koncentracji struktury agrarnej świadczy także rosnący udział gospodarstw o powierzchni powyżej 15 ha UR w strukturze gospodarstw, który w latach 1996-2018 wzrósł o 7 p.p. (z 8\% do 15\%), zaś ich udział w powierzchni użytków rolnych w kraju, zwiększał się aż o 29,4 p.p., osiągając poziom $60,4 \%$.

Tabela 1. Zmiany struktury agrarnej oraz zasobów pracy w rolnictwie w Polsce w latach 1996-2018

\begin{tabular}{|c|c|c|c|c|c|c|}
\hline \multirow[t]{2}{*}{ Rok } & \multirow[t]{2}{*}{$\begin{array}{c}\text { Areał UR } \\
(\mathrm{mln} \text { ha) }\end{array}$} & \multirow{2}{*}{$\begin{array}{c}\text { Przeciętna } \\
\text { powierzchnia } \\
\text { gospodarstwa } \\
\text { w ha UR }{ }^{1}\end{array}$} & \multicolumn{2}{|c|}{$\begin{array}{l}\text { Gospodarstwa o po- } \\
\text { wierzchni } 15 \text { ha UR } \\
\text { i więcej }\end{array}$} & \multirow[t]{2}{*}{$\begin{array}{l}\text { Liczba ha } \\
\text { UR na } \\
\text { AWU }^{2}\end{array}$} & \multirow[t]{2}{*}{$\begin{array}{c}\text { Liczba AWU } \\
\text { przypadających } \\
\text { na } 100 \text { ha UR }\end{array}$} \\
\hline & & & $\begin{array}{c}\text { odsetek } \\
(\%)^{1}\end{array}$ & $\begin{array}{c}\text { udział w } \\
\text { powierzchni } \\
\text { UR }^{1}\end{array}$ & & \\
\hline 1996 & 17,88 & 7,6 & 8,0 & 31,0 & 5,31 & 18,84 \\
\hline 1998 & 17,87 & 7,8 & 9,3 & 38,0 & 6,26 & 15,98 \\
\hline 2000 & 17,81 & 8,0 & 9,9 & 40,4 & 7,14 & 14,01 \\
\hline 2002 & 16,90 & 8,4 & 10,2 & 44,7 & 7,03 & 14,22 \\
\hline 2004 & 16,33 & 8,5 & 10,3 & 46,2 & 7,15 & 13,98 \\
\hline 2006 & 15,95 & 8,6 & 11,1 & 51,6 & 7,13 & 14,02 \\
\hline 2008 & 16,15 & 8,8 & 11,5 & 52,8 & 7,36 & 13,58 \\
\hline 2010 & 15,46 & 9,2 & 13,2 & 56,8 & 7,56 & 13,59 \\
\hline 2012 & 15,57 & 10,1 & 14,1 & 58,4 & 8,04 & 12,44 \\
\hline 2014 & 15,16 & 10,4 & 14,8 & 59,7 & 8,12 & 12,31 \\
\hline 2016 & 14,98 & 10,4 & 14,9 & 59,8 & 8,94 & 11,19 \\
\hline 2018 & 14,62 & 10,5 & 15,0 & 60,4 & 8,72 & 11,46 \\
\hline
\end{tabular}

${ }^{1}$ dotyczy gospodarstw o obszarze powyżej 1 ha UR

${ }^{2}$ Jednostka przeliczeniowa pracy (pełnozatrudniony) - stanowi równowartość 2120 godzin pracy w roku.

Źródło: Roczniki statystyczne rolnictwa z lat 2002-2018, GUS, Warszawa; Użytkowanie gruntów i powierzchnia zasiewów z lat 2003-2018, GUS, Warszawa oraz dane Eurostat, http:pp.eurostat.ec.europa.eu.

Nakłady pracy w polskim rolnictwie, mierzone w tzw. AWU (Annual Work Unit), czyli szacunkowych jednostkach pełnozatrudnionych, zmniejszyły się w latach 19962018 z 3.368,8 tys. AWU do $1.675,8$ tys. AWU ${ }^{7}$. Tak znaczący, bo sięgający 50,3\% spadek nakładów siły roboczej, w połączeniu z sukcesywnym zmniejszaniem się zasobów ziemi użytkowanej rolniczo, spowodował istotne zmiany w relacjach tych czynników w rolnictwie (tab. 1). Należy jednak podkreślić, że w jednostkach silniejszych eko-

\footnotetext{
${ }^{7}$ Eurostat: Agricultural labour input statistics: absolute figures (1 000 annual work units), eurostat.ec.europa.eu/nui/setupDownloads.do (dostęp: 12.07.2019).
} 
nomicznie, nastawionych na produkcję towarową, dla których reprezentatywne są dane rachunkowości rolnej FADN (około 730 tys. gospodarstw w kraju), redukcja zatrudnienia była znacznie mniejsza, bowiem wynosiła $6,8 \% \mathrm{w}$ latach $2004-2017^{8}$, podczas gdy w całym sektorze wyniosła w tym czasie $26,6 \%$.

W ślad za postępującą koncentracją ziemi poprawiała się produktywność tego czynnika wytwórczego. Przykładowo, produktywność ziemi wyrażona wolumenem produkcji końcowej na 1 ha UR, osiagała w latach 1995-2003 realną średnioroczną stopę wzrostu na poziomie $3,3 \%$, natomiast w latach 2004-2018, realna stopa wzrostu wynosiła 4,4\%. Wartość dodana brutto na pełnozatrudnionego (AWU) w cenach nominalnych osiągnęła w roku 2018 wartość 4-krotnie wyższą niż w roku 2003, zaś realnie była wyższa o $130,9 \%$ (deflator - indeks cen globalnej produkcji rolnej). W latach 1996-2003 wielkość ta rosła realnie około 2,4\% rocznie, natomiast w latach 2004-2017 osiagnęła średnioroczną realną stopę wzrostu $6,1 \%$.

Wzrost produktywności rolnictwa w Polsce, obserwowany szczególnie w okresie poakcesyjnym, przy zmniejszeniu nakładów pracy i ziemi, był efektem wzrostu nakładów kapitałowych (rys. 3). W latach 1998-2004 nakłady inwestycyjne w rolnictwie wykazywały średnioroczny spadek $-5,74 \%$ (w przeliczeniu na 1 ha UR, w cenach stałych). Dopiero rok po przystapieniu Polski do UE, wzrost wydatków budżetowych na rolnictwo (z funduszy WPR i budżetu krajowego) spowodował impuls inwestycyjny, wyrażający się w średniorocznej stopie wzrostu nakładów inwestycyjnych, w przeliczeniu na 1 ha UR, wynoszącej 5,7\%, dla lat 2005-2017, przy czym w roku 2009 i w latach 2016-2017 można było obserwować nieznaczne negatywne odchylenie od tej tendencji wzrostowej (rys. 3).

W efekcie wzrostu inwestycji w rolnictwie od 2005 r. postępował wzrost technicznego uzbrojenia pracy i technicznego uzbrojenia ziemi, czyli wartości środków trwałych przypadającej odpowiednio na pełnozatrudnionego i na 1 ha UR. Wartość brutto środków trwałych na AWU (w cenach ewidencyjnych) była w 2017 roku o 163,2\% wyższa niż w roku 1996, zaś w porównaniu do roku 2004, była wyższa o 77,8\%. Z kolei wartość środków trwałych przypadająca na 1 ha UR w roku 2017 była wyższa o 59,5\% w stosunku do roku 1996 (45,1\% w stosunku do 2004 r.). Należy podkreślić, że wzrost nakładów kapitałowych $\mathrm{w}$ rolnictwie był $\mathrm{w}$ pewnej części finansowany $\mathrm{z}$ kredytów bankowych - o czym była mowa wcześniej - w znacznej części był jednak finansowany z funduszy publicznych, które szerokim strumieniem napływały do rolnictwa po roku 2004. W latach 2004-2018 wydatki budżetowe na rolnictwo $z$ funduszy UE i budżetu krajowego (z wyłączeniem dotacji na KRUS) wynosiły przeciętnie 29,7 mld zł (od 9,6 mld zł w roku 2004 do 37,8 mld zł w 2015 r.), podczas gdy w latach 1996-2003 wynosiły przeciętnie 4,6 mld zł. Oznacza to nominalnie blisko 6,5-krotny wzrost wydatków na rolnictwo, rynki rolne i rozwój wsi, co nie pozostało bez wpływu na skalę inwestycji w rolnictwie ${ }^{\text {. }}$.

\footnotetext{
${ }^{8}$ FADN: Wyniki Standardowe 2017 uzyskane przez gospodarstwa rolne uczestniczące w Polskim, IERiGŻPIB, Warszawa 2018.

${ }_{9}^{9}$ A. Czyżewski, R. Kata, A. Matuszczak: Wpływ krajowych i unijnych wydatków budżetowych na alokację czynników produkcji w polskim rolnictwie, Ekonomista, 1/2019, s. 45-72.
} 


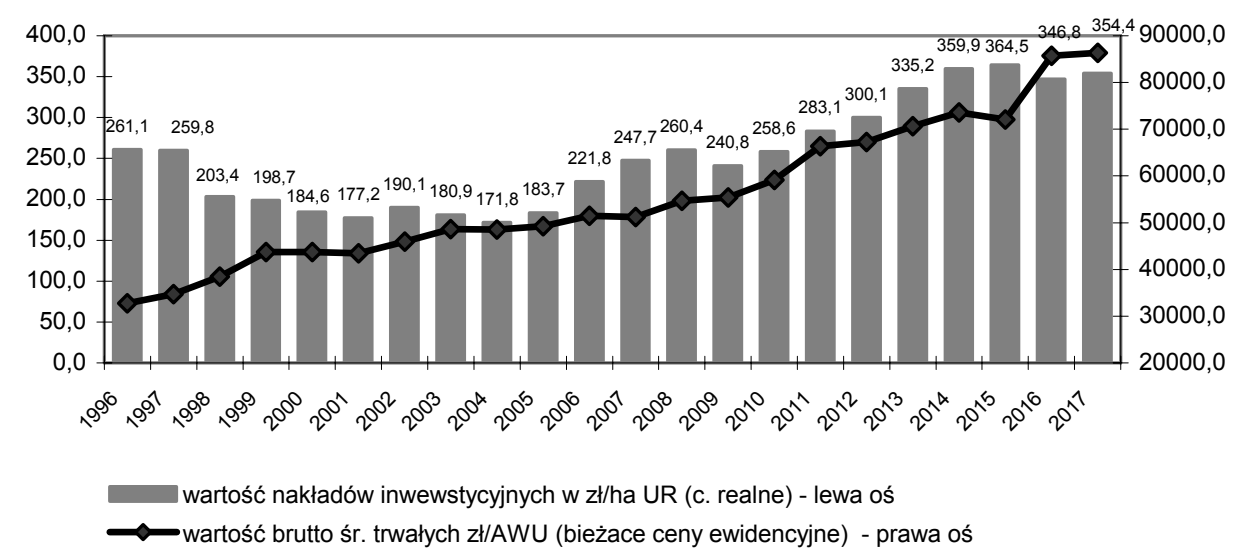

Rysunek 3. Realne nakłady inwestycyjne w rolnictwie w zł/ha UR oraz wartość środków trwałych (w cenach ewidencyjnych) w przeliczeniu na pełnozatrudnionego (zł/AWU) w latach 1996-2017.

Źródło: Roczniki statystyczne rolnictwa z lat 2002-2018, GUS, Warszawa.

Wzrost wydatków budżetowych na rolnictwo po 2004 roku, oddziaływał na popyt kredytowy rolników w dwóch przeciwstawnych kierunkach. Z jednej strony wspierał ten popyt, gdyż kredyty bankowe, w przypadku przedsięwzięć inwestycyjnych dotowanych ze środków publicznych, są często niezbędne do montażu finansowego, na który składają się środki własne rolnika, dotacja inwestycyjna i kredyt bankowy. Potrzeba skorzystania z kredytu bankowego wynika z faktu, że dotacje inwestycyjne z funduszy UE zwykle refundują część kosztów inwestycji. Rolnik musi zatem pokryć je środkami własnymi lub sięgnąc po zwrotne źródła finansowania, tj. zwykle po kredyt bankowy (np. kredyt pomostowy). Z drugiej strony, wzrost wydatków budżetowych na rolnictwo może zmniejszać zainteresowanie rolników kredytami bankowymi. Dzieje się tak, gdy występuje efekt wypierania $z$ procesów finansowania rolnictwa funduszy prywatnych o charakterze zwrotnym przez fundusze publiczne w formie subsydiów i dotacji. Wzrost wydatków budżetowych na rolnictwo, w tym transfery w formie dopłat bezpośrednich mogły na tyle poprawić sytuację finansową rolników (akumulację funduszy własnych), że nie byli oni zainteresowani sięganiem po kredyty. Teza ta koreluje $\mathrm{z}$ wspomnianym wcześniej wynikami badań IRG SGH, które wyraźnie pokazują, że od 4 kw. 2006 r., czyli około 1,5 roku po uruchomieniu strumienia dopłat bezpośrednich i około roku po uruchomieniu dotacji inwestycyjnych dla rolników, kształtuje się bardzo wyraźny trend spadkowy w zakresie zamiaru wzięcia kredytu przez rolników ${ }^{10}$.

Biorąc pod uwagę wymienione fakty, podjęto analizę statystyczną w celu ustalenia, czy wśród czynników determinujących zadłużenie kredytowe rolników, istotną rolę pełni koniunktura $\mathrm{w}$ rolnictwie oraz przemiany strukturalne $\mathrm{w}$ tym sektorze. Do analizy wprowadzono także zmienną - stopa subsydiowania gospodarstw rolnych ${ }^{11}$, w celu

\footnotetext{
${ }^{10}$ IRG SGH: Koniunktura w rolnictwie IV kwartał 2018. SGH, Warszawa 2018, s. 39.

${ }^{11}$ Udział dopłat do działalności operacyjnej w dochodzie dyspozycyjnym brutto gospodarstw rolniczych (w \%)
} 
wyjaśnienia współzależności pomiędzy zadłużeniem rolników a wsparciem budżetowym dla rolnictwa. Jako zmienną zależną $\mathrm{Y}_{1}$ przyjęto realny, tj. wyrażony $\mathrm{w}$ cenach stałych (w mln zł), poziom zadłużenia rolników w bankach w latach 1996-2018.

Tabela 2. Współczynnik korelacji liniowej pomiędzy realną kwotą zadłużenia kredytowego rolników $\mathrm{Y}_{1}$, a zmiennymi opisującymi koniunkturę i przemiany strukturalne $\mathrm{w}$ rolnictwie $\mathrm{w}$ latach $1996-2018$

\begin{tabular}{|l|c|}
\hline \multicolumn{1}{|c|}{ Zmienne niezależne } & Y1 \\
\hline $\mathrm{X}_{1}-$ Indeks nożyc cen w rolnictwie & 0,0179 \\
\hline $\mathrm{X}_{2}-$ Wskaźnik koniunktury IGRAGR & $0,5987^{*}$ \\
\hline $\begin{array}{l}\mathrm{X}_{3}-\text { Przeciętna powierzchnia gospodarstw w ha UR (proces koncentracji struktury } \\
\text { agrarnej) }\end{array}$ & $0,9752^{*}$ \\
\hline $\mathrm{X}_{4}$ - Liczba ha UR na AWU (zmiany relacji praca/ziemia) & $0,8760^{*}$ \\
\hline $\mathrm{X}_{5}-$ Wartość brutto środków trwałych na AWU (zmiany relacji kapitał/praca) & $0,9772^{*}$ \\
\hline $\mathrm{X}_{6}-$ Wartość brutto środków trwałych na ha UR (zmiany relacji kapitał/ziemia) & $0,9897^{*}$ \\
\hline $\mathrm{X}_{7}-$ Nakłady inwestycyjne w zł/ha UR (w cenach stałych) & $0,8588^{*}$ \\
\hline $\mathrm{X}_{8}-$ Stopa subsydiowania gospodarstw rolnych (\%) & $0,8048^{*}$ \\
\hline
\end{tabular}

Istotność statystyczna: * $\mathrm{p}<0,05$

Źródło: obliczenia własne na podstawie danych NBP, GUS i IRG SGH (2018).

W tabeli 2 wykazano cechy, które zostały wybrane jako zmienne objaśniające $\left(\mathrm{X}_{\mathrm{i}}\right)$ oraz zaprezentowano wartości współczynników korelacji liniowej Pearsona pomiędzy badanymi cechami a zmienną zależną $Y_{1}$. Dokonano także analizy korelacji pomiędzy zmienną $Y_{2}$, tj. dynamiką zadłużenia rolników w cenach stałych (rok do roku, w \%), a zmiennymi $X_{\mathrm{i}}$. W tym przypadku istotną statystycznie korelację (na poziomie $\mathrm{p}<0,05$ ) wykazały tylko dwie zmienne, tj. liczba ha UR/AWU $\left(\mathrm{r}_{\mathrm{xy}}=0,427\right)$ oraz indeks nożyc cen $\left(\mathrm{r}_{\mathrm{xy}}=0,389\right)$. Wobec powyższego estymację modelu regresji przeprowadzono dla zmiennej $Y_{1}$.

Analiza wykazała, że wszystkie cechy objaśniające, oprócz zmiennej $X_{1}$ - indeks nożyc cen, są istotnie statystycznie skorelowane ze zmienną objaśnianą $Y_{1}$, tj. realnym zadłużeniem kredytowym rolników (tab. 2). Współczynniki korelacji mają znak dodatni i relatywnie wysokie wartości, co sugeruje, że są to czynniki, które mogą w istotnym zakresie determinować zadłużenie kredytowe rolników. Problem polega jednak na tym, że analizie poddawane są szeregi czasowe i wobec tego może wystąpić sytuacja, że dwa szeregi czasowe mają taki sam (np. wzrostowy) trend, a zatem współczynnik korelacji będzie wysoki i dodatni, ale nie będzie zachodzić pomiędzy nimi współzależność. Biorąc powyższe pod uwagę - aby wykluczyć pozorne powiązania między zmiennymi, wynikające ze współwystępowania ich trendów, estymację modelu regresji poprzedziła analiza stacjonarności zmiennych za pomocą testu ADF oraz analiza kointegracji szeregów czasowych. Wyniki testu $\mathrm{ADF}^{12}$ wykazały, że wszystkie zmienne niezależne (poza $\mathrm{X}_{1}$ ) oraz zmienna zależna $\mathrm{Y}_{1}$ posiadają pierwiastek jednostkowy.

Największą wartość diagnostyczną uzyskano dla równania regresji o postaci:

$$
\Delta \mathrm{Y}_{1, \mathrm{t}}=\alpha_{0}+\alpha_{1 \Delta} \mathrm{X}_{3, \mathrm{t}}+\alpha_{2} \Delta \mathrm{X}_{4, \mathrm{t}}+\alpha_{3} \Delta \mathrm{X}_{7, \mathrm{t}}+\alpha_{4} \Delta \mathrm{X}_{8, \mathrm{t}}+\boldsymbol{\varepsilon}_{\mathrm{t}}
$$

12 Wyniki testu ADF ( $p$-value) odpowiednio dla poziomów i pierwszych różnic zmiennych: $\mathrm{Y}_{1}$ : $\mathrm{p}=0,119 / \mathrm{p}=0,02 ; \mathrm{X}_{3}: \mathrm{p}=0,41 / \mathrm{p}=0,005 ; \mathrm{X}_{4}: \mathrm{p}=0,11 / \mathrm{p}=0,03 ; \mathrm{X}_{5}: \mathrm{p}=0,78 / \mathrm{p}=0,003 ; \mathrm{X}_{6}: \mathrm{p}=0,64 / \mathrm{p}=0,003 ; \mathrm{X}_{7}$ : $\mathrm{p}=0,55 / \mathrm{p}=0,01 ; \mathrm{X}_{8}: \mathrm{p}=0,86 / \mathrm{p}=0,008$. 
gdzie:

$\mathrm{Y}_{1}$ - realne zadłużenie kredytowe rolników ( $\mathrm{w}$ mln zł),

$\mathrm{X}_{3}, \mathrm{X}_{4}, \mathrm{X}_{7}, \mathrm{X}_{8}$ - oznaczenia zmiennych jak w tabeli 2,

$\boldsymbol{\varepsilon}_{\mathrm{t}}$ - błąd losowy,

$\mathrm{t}$ - czas.

Taka postać funkcji oznacza, że ustalany jest wpływ zmiennych $\mathrm{X}_{i}$ nie na poziom, lecz na przyrost zadłużenia kredytowego rolników. Podobnie w odniesieniu do zmiennych $\mathrm{X}_{i}$ (poza zmienną $\mathrm{X}_{1}$ ) uwzględniana jest ich zmiana (przyrost) w stosunku do roku poprzedniego, nie zaś ich poziom. $\mathrm{W}$ oszacowaniu równania regresji wykorzystano metodę MNK.

Tabela 3. Parametry funkcji regresji określającej determinanty zadłużenia rolników (w ujęciu realnym) $\left(\mathrm{Y}_{1}\right)$ w latach 1996-2018 $(\mathrm{N}=22)$

\begin{tabular}{|c|c|c|c|c|c|}
\hline Parametry funkcji & współczynnik & błąd st. (HAC) & t-Studenta & wartość p & istotność \\
\hline Const. & 1521,81 & 253,66 & 5,999 & $1,85 \mathrm{e}-05$ & $\begin{array}{r}* * \\
*\end{array}$ \\
\hline $\begin{array}{l}\Delta \mathrm{X}_{3} \text { - przeciętna powierzchnia } \\
\text { gospodarstw (w ha UR) }\end{array}$ & $-1643,45$ & 523,962 & $-3,137$ & 0,0064 & $* * *$ \\
\hline$\Delta \mathrm{X}_{4}-$ liczba ha UR/AWU & $-818,92$ & 363,024 & $-2,256$ & 0,0384 & $* *$ \\
\hline $\begin{array}{l}\Delta \mathrm{X}_{7}-\text { nakłady inwestycyjne w } \\
\text { zł/ha UR (w c. stałych) }\end{array}$ & 28,46 & 5,786 & 4,919 & 0,0002 & $* * *$ \\
\hline $\begin{array}{c}\Delta \mathrm{X}_{8}-\text { stopa subsydiowania } \\
\text { gospodarstw rolnych }(\%)\end{array}$ & $-21,1876$ & 10,7755 & $-1,966$ & 0,0669 & $*$ \\
\hline \multicolumn{6}{|c|}{$\begin{array}{l}\text { Suma kwadratów reszt } 11124178 ; \text { Błąd stand. reszt } 833,8232 ; \\
\text { Istotność statystyczna: }{ }^{* * *} \mathrm{p}<0,001 ; * * \mathrm{p}<0,05 ; * \mathrm{p}<0,1 \\
\mathrm{R}^{2} 0,5116 \text {; Skorygowany } \mathrm{R}^{2} 0,3951 ; \mathrm{F}(4,16) 17,8193 ; \text { Wartość } \mathrm{p} \text { dla testu } \mathrm{F} 0,0000096 ; \text { rho1 } 0,05 \\
\text { Test na normalność rozkładu reszt Doornika-Hansena: } \mathrm{p}=0,319 \\
\text { Test White'a na heteroskedastyczność reszt: } \mathrm{p}=0,695 ; \text { Test LM na autokorelację rzędu } 1: \mathrm{p}=0,809 \\
\text { Test ADF dla reszt modelu: } \mathrm{p}=0,013\end{array}$} \\
\hline
\end{tabular}

Źródło: obliczenia własne.

Wyniki oszacowania dla modelu regresji o największej wartości diagnostycznej (tab. 3), wskazują, że realne zadłużenie kredytowe rolników rośnie wówczas, gdy rosną (względem roku poprzedniego) realne nakłady inwestycyjne $\mathrm{w}$ rolnictwie (w przeliczeniu na 1 ha UR). Taka zależność jest zgodna z oczekiwaniami. Natomiast interesujące jest to, że pozostałe zmienne niezależne, które znalazły się w równaniu regresji ujawniły ujemną współzależność ze zmienną $\Delta \mathrm{Y}_{1}$. Interpretacja zależności ujawnionych w równaniu regresji (tab. 3), przy założeniu ceteris paribus, jest następująca:

- wzrost przeciętnego obszaru gospodarstw rolnych $\left(\Delta X_{3}\right)$ oraz poprawa relacji zie$\mathrm{mia} /$ praca w kierunku wzrostu areału użytków rolnych na AWU $\left(\Delta \mathrm{X}_{4}\right)$, a zatem postęp w procesie koncentracji struktury agrarnej, powoduje obniżenie tempa przyrostu zadłużenia rolników;

- wzrost stopy subsydiowania gospodarstw rolnych $\left(\Delta \mathrm{X}_{8}\right)$, czyli transferu środków budżetowych do rolnictwa, powoduje zmniejszenie przyrostu zobowiązań kredytowych rolników;

Jakość dopasowania modelu regresji, wyrażona współczynnikiem $\mathrm{R}^{2}$, nie jest zbyt wysoka $\left(\mathrm{R}^{2}=0,51\right)$, co nie może jednak dziwić, gdyż na tempo przyrostu zadłużenia kredytowego rolników wpływa wiele nieuwzględnionych w modelu czynników makro- 
ekonomicznych, takich jak sytuacja polityczno-ekonomiczna, ogólna koniunktura gospodarcza, sytuacja na rynkach rolnych i związane z tym nastroje rolników. Należy też pamiętać, że wpływ polityki makroekonomicznej na decyzje podejmowane przez rolników charakteryzuje się pewnymi opóźnieniami czasowymi (nawet rocznymi).

\section{Podsumowanie}

Badania nie dały jednoznacznej odpowiedzi na pytanie dotyczące wpływu koniunktury w rolnictwie (ujmowanej obiektywnie i subiektywnie) oraz wpływu zmian strukturalnych $\mathrm{w}$ tym sektorze na poziom zadłużenia rolników w bankach. Biorąc pod uwagę analizę korelacji można wysunać ostrożny wniosek, że poprawa koniunktury w rolnictwie sprzyja popytowi rolników na kredyty. Przy czym nieco silniejszą relację dodatnią wykazuje wskaźnik koniunktury ujmujący subiektywne oceny perspektyw finansowych gospodarstwa, niż obiektywny indeks nożyc cen. Analiza korelacji wskazuje także na współwystępowanie trendu wzrostowego zadłużenia rolników z wzrostem technicznego uzbrojenia pracy i technicznego uzbrojenia ziemi, co jawi się jako związek logiczny, gdyż wymienione procesy strukturalne wynikają z substytucji malejących nakładów pracy i ziemi przez nakłady kapitału. To te procesy były odpowiedzialne za wzrost produktywności polskiego rolnictwa $w$ latach 2004-2018. Niemniej analiza regresji nie wykazała istotnych statystycznie powiązań pomiędzy omawianymi zmiennymi, co nie wyklucza, że związek istnieje, kwestia ta wymaga jednak dalszych badań. Parametry funkcji regresji wskazały z kolei, że na zadłużenie rolników istotny wpływ mają przemiany w strukturze agrarnej, a ściślej koncentracja zasobów ziemi w mniejszej liczbie gospodarstw rolnych oraz wzrost relacji ziemia/praca w rolnictwie. Wymienione procesy prowadzą do wzrostu potencjału wytwórczego gospodarstw oraz pełniejszego wykorzystania zasobów pracy. Silniejsze i lepiej zorganizowane gospodarstwa mogą wykazywać mniejsze zainteresowanie kredytami bankowymi, zwłaszcza w warunkach relatywnie dużej dostępności funduszy zewnętrznych o charakterze bezzwrotnym (subwencje, dotacje), które wspierają działalność operacyjna, jak i procesy modernizacyjno-rozwojowe gospodarstw. W świetle wyników badań można wysunąć wniosek, że postępujące przemiany strukturalne $\mathrm{w}$ rolnictwie nie prowadzą do zmniejszenia zadłużenia rolników, a jedynie hamują tempo wzrostu ich zadłużenia. Biorcą pod uwagę skalę zadłużenia aktywów gospodarstw rolnych w Polsce $(5,4 \%$ w 2016 r.), która jest 3-krotnie niższa, niż średnia dla $\mathrm{UE}^{13}$, można zakładać, że znaczenie kredytów bankowych w finansowaniu gospodarstw rolnych będzie rosło, a przemiany strukturalne należy w tym kontekście postrzegać jako stymulantę tego procesu.

\section{Bibliografia}

Barry P.J., Robison L.J.: Agricultural Finance: Credit, Credit Constraints, and Consequences. Handbook of Agricultural Economics, 1(A)/2001.

Bierlen R., Barry P.J., Dixon B.L., Ahrendsen B.: Credit Constraints, Farm Characteristics and the Farm Economy. American Journal of Agricultural Economics, vol. 80, nr 4/1998.

\footnotetext{
${ }^{13}$ Kata R., 2018: Dynamika i struktura zadłużenia kredytowego gospodarstw rolniczych w Polsce. Roczniki Naukowe SERiA, t. XX, z. 5/2018, s. 74-80
} 
Blancard S., Boussemart J.P., Briec W., Kerstens K.: Short- and Long-Run Credit Constraints in French Agriculture: A Directional Distance Function Framework Using Expenditure-Constrained Profit Functions. American Journal of Agricultural Economics, vol. 88, issue 2/2006.

Czyżewski A., Kata R., Matuszczak A.: Wplyw krajowych i unijnych wydatków budżetowych na alokację czynników produkcji w polskim rolnictwie, Ekonomista, nr 1/2019.

Eurostat: Agricultural labour input statistics: absolute figures (1 000 annual work units), eurostat.ec.europa.eu/nui/setupDownloads.do (dostęp: 12.07.2019).

FADN: Wyniki Standardowe 2017 uzyskane przez gospodarstwa rolne uczestniczace w Polskim, IERiGŻ-PIB, Warszawa 2018.

Grzelak A., 2014: Koniunktura w rolnictwie w Polsce w świetle wybranych metod. Roczniki

Naukowe SERiA, t. XVI, z. 2.

Kata R.: Endogeniczne i instytucjonalne czynniki ksztaltujace powiazania finansowe gospodarstw rolnych z bankami, Wyd. Uniwersytetu Rzeszowskiego, Rzeszów 2011.

Kata R.: Dynamika i struktura zadtuzenia kredytowego gospodarstw rolniczych w Polsce. Roczniki Naukowe SERiA, t. XX, z. 5/2018.

IRG SGH: Koniunktura w rolnictwie IV kwartat 2018. SGH, Warszawa 2018.

Kulawik J., Wieliczko B.: Polityka pieniężna a kredytowanie rolnictwa. Zagadnienia Ekonomiki Rolnej, nr 337(4)/2013.

Kułyk P.: Uwarunkowania rynku kredytowego w rolnictwie. Ujęcie makroekonomiczne, Progress in Economic Sciences, $\mathrm{nr}$ 1/2014.

NBP: https://www.nbp.pl/home.aspx?f=/statystyka/pieniezna_i_bankowa (dostęp: 12.07.2019).

Wasilewski M., Mądra M.: Efektywność gospodarstw indywidualnych w zależności od zadłużenia i siły ekonomicznej. Ekonomika i Organizacja Gospodarki Żywnościowej, nr 64/2008.

\section{Summary}

The paper presents an analysis of the dynamics and structure of farmers' credit obligations towards banks in Poland in 1996-2018. The credit debt of farmers is presented against the background of the structural changes and economic fluctuations in agriculture. It was assumed that a favorable economic situation in agriculture stimulates the growth in farmers' indebtedness to banks. Similarly, it was assumed that the process of increasing concentration within the agrarian structure and the increase in the technical equipment of labor and technical equipment of land would be factors conducive to the growth in farmers' credit debt. The research did not give a definite answer to the research thesis. A positive correlation between farmers' credit debt and economic fluctuations in agriculture was revealed, as well as the process of substitution of labor and land inputs by capital expenditures. Regression analysis showed that investment stimulus in agriculture is the stimulus of credit debt, while increased concentration within the agrarian structure and the improvement of the land/work relationship leads to a reduction in debt increases.

Key words: agricultural holdings, bank credit, economic fluctuations in agriculture, structural changes.

JEL Codes: G21, Q14.

Informacje o autorze:

dr hab. Ryszard Kata, prof. UR

Uniwersytet Rzeszowski, Wydział Ekonomii

ul. Ćwiklińskiej 2, Rzeszów, Polska

e-mail: rdkata@univ.rzeszow.pl

ORCID: 0000-0001-6085-3935 